\title{
Hematoporphyrin 誘導体の腫瘍親和性に関する基礎的研究
}

(II) Hp-diacetate ならびに Hp-disilate の担癌ラットに拈ける体内動態

$\begin{array}{ccccc} & \text { 森 } & & & \text { 久 } \\ & \text { 加 } & \text { 藤 } & \text { 哲 } & \text { 郎 } \\ & \text { 阿 } & \text { 部 } & \text { 良 } & \text { 悦 } \\ \text { 秋田大学泌尿器科教室 } & \text { 守 } & \text { 山 } & \text { 正 } & \text { 片 } \\ & \text { 佐 } & \text { 藤 } & \text { 一 } & \text { 成 } \\ & \text { 鈴 } & \text { 木 } & \text { 敏 } & \text { 男 } \\ & \text { 佐 } & \text { 藤 } & \text { 悦 } & \text { 子 }\end{array}$

\section{EXPERIMENTAL STUDIES ON TUMOR SPECIFICITY OF HEMATOPORPHYRIN DERIVATIVES}

II. Kinetics of Hematoporphyrin Diacetate and Hematoporphyrin Disilate in Tumor Bearing Rats

Hisashi Mori, Tetsuro Kato, Ryoetsu Abe, Masatsugu Moriyama, Kazunari Sato, Toshio Suzuki and Etsuko Sato Department of Urology, Akita University School of Medicine (Director. Prof. Seigi Tsuchida)

Kinetics of hematoporphyrin diacetate (Hp-diAc) and hematoporphyrin disilate (Hp-diSi), which were synthesized as single chemical compounds, were investigated in rats with subcutaneously transplanted AH-109A hepatocellular tumor. Hematoporphyrin derivative (Hp-D), a complex mixture of several porphyrins, was used as the control. The agents were given intravenously at a dose of $10 \mathrm{mg} / \mathrm{kg}$; tissue specimens obtained as predetermined intervals were submitted to fluorescent microscopic observation and porphyrin concentration in the tissues was assessed with a fluorescent spectrophotometer.

Hp-diAc, Hp-diSi and Hp-D showed, in general, a trend of tissue distribution in the following order: 《liver, spleen 》tumor, kidney, lung>testis, muscle. Hp-diAc and Hp-D levels in these tissues gradually decreased, while Hp-diSi was retained for a longer period of time up to 96 hours after injection. Tumor surrounding muscle ratio of porphyrin concentration (T/M value) ranged from 2.7 to 7.5 for Hp-D and from 3.7 to 6.6 for Hp-diSi, indicating a high intratumorous accumulation of these two substances. On the other hand, T/M value of $\mathrm{Hp}$-diAc remained at a low level ranging from 1.0 to 1.7.

The present study suggests the possible usefulness of $\mathrm{Hp}$-diSi as a porphyrin with tumor affinity.

要旨：塩酸へマトポルフィリンから単一化合物として誘導した hematoporphyrin diacetate (Hp-diAc) と hematoporphyrin disilate (Hp-diSi) の体内動態を, ポルフィリン混合体であるいわゆるへマトポル フィリン誘導体（Hp-D）と対比して観察した. 実験モデルには, AH 109A 皮下腫瘍を移植したラット

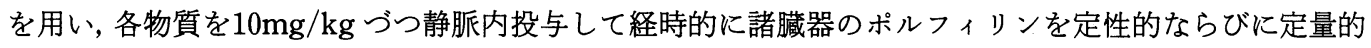
に追跡した。

各物質の組織内濃度の全般的傾向は肝 $>$ 脾》腫瘍, 腎・肺 $>$ 䆺丸, 腫瘍周囲筋の順であった. 組織内 濃度の経時的変化は, Hp-D と Hp-diAc は全般的に漸減傾向をみせたのに対し, Hp-diSi は持続停滞す る傾向が認められた。

腫瘍周囲筋に対する腫瘍組織内濃度比( $\mathrm{T} / \mathrm{M}$ 比)をみると, Hp-D と Hp-diSi はそれぞれ7.5ならびに 
6.6の値を投与後 24 48時間にわたって示した。 これに対して Hp-diAc の T/M 比は1.7 1.0 低値を 示した。この結果は Hp-diSi の腫瘍親和性を示すものと考学られる.

\section{緒言}

Lipson ら'が開発したへマトポルフィリン誘導体 （Hp-D）は腫揚親和性を有することから，その臨床応 用について広く研究がす寸められている物質であ る2) 5). しかし前報 ${ }^{6)}$ に述べた如く, Hp-D は数種の化 合物の混合物であり，その中には未確認の化合物が含 まれている。さらにその複雑な合成過程のため, Hp-D の組成が微妙に变化する欠点が指摘される。そこで著 者らは，へマトポルフィリンから単一化合物を効率よ く誘導することを目的として新しい合成法を考案し， これによって Hp-Dのアルカリ処理前の主成分である hematoporphyrin diacetate (Hp-diAc) を合成した。 同時に全く新しい誘導体である hematoporphyrin disilate (Hp-diSi) をも合成することができた。

前報では Hp-diAc と Hp-diSi の合成法と,これらの 両物質の物理化学的性質を明らかにするとともに，培 養癌細胞と腹水腫瘍細胞への取り込みを観察した。そ の結果, 両物質はポルフィリン属に共通する物理化学 的性質を有し，また腫瘍細胞親和性を有することを強 く示唆する成績を得ることができた。しかし Hp-D， Hp-diAc ならびに Hp-diSi を比較するとこれら 3 者 の腫瘍親和性に少なからず相違があることが示され た。また，これら化合物を薬剤として生体に適用する 場合には，各物質の体内動態を明らかにする必要があ る。

そこで著者らは皮下固形腫瘍の実験動物モデルを対 象とし, Hp-D, Hp-diAc ならびに Hp-diSi の生体内分 布を形態的ならびに定量的に追跡した。

\section{材料ならびに方法}

1. 動物実験モデルと薬剤投与：日本クレハ CE2自 由摂取下で飼育した呑竜ラット（雄性 $8 \sim 10$ 週齢，平 均体重200g）の腹部皮下に，腹水腫湟として継代した $\mathrm{AH} 109 \mathrm{~A}$ 腹水肝癌細胞 $10^{7}$ 二を移植した。 移植 10 日後 に腫瘍径が1.5 2.0cm になった時点で，Hp-D， HpdiAc ならびに Hp-diSi をそれぞれ $10 \mathrm{mg} / \mathrm{kg}$ づつ頝静 脈に注入した。

2. 組織内分布の形態的観察：上述のように作製し た担癌ラット 24 頭に Hp-D ならびに Hp-diSiをそれ ぞれ静注投与し，投与 $6,12,24 な ら ひ ゙ に 48$ 時間後に各 群 3 頭づつ屠殺した。腫瘍, 腫崵周囲の筋, 肝, 脾, 肺, 腎, 辠丸ならびに腸を摘出し, 生理食塩水で洗浄
後ただちに TISSUE-TEK II で試料を包埋してドラ イアイスで涷結した。クリオスタットで各試料から凍 結切片標本を作製し, $\mathrm{V}$ 励起下の蛍光顕微鏡 (OLYMPUS VANOX) で標本を観察した. 赤色蛍光 を各物質の取り込み指標とし, その程度を強度 $(+$ H), 中 等度 $(+)$, 弱度 $( \pm)$, 陰性 (一) の 4 段階に分類した。 な新本実験では Hp-diAc は省略した。

3. 組織内取り込みの定量的分析：前述のよ5に作 成した担癌ラット115頭を 3 群に分け, Hp-D, Hp-diAc ならびに Hp-diSiをそれぞれ $10 \mathrm{mg} / \mathrm{kg}$ づつ静注投与 した. $0,3,6,12,24,48,72,96$ 時間後に, 各群 4 ～ 5 頭のラットを心穿刺によって生理食塩水 $200 \mathrm{ml}$ を 用いた脱血潅流で屠殺した。腫湟，その周囲の筋，肝， 脾, 肺, 腎ならびに睾丸を摘出し, 各臟器から正確に $1.0 \mathrm{~g}$ の試料を採取した。但し, 腫瘍では中心部壊死組 織を除いた部分を試料とし, 脾は $1.0 \mathrm{~g}$ に満たないため 全量を試料として測定值は重量単位に換算した。

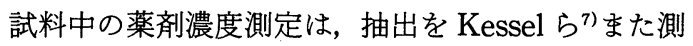
定を Dougherty $5^{8)}$ の方法に準じ，有機溶媒抽出物の 蛍光強度によって算出した。すなわち試料（1）に生理 食塩水(2) と $1 \%$ EDTA-2Na（0.5）を加觉てホモジナ イズしこれに $30 \%$-trichloroacetic acid solution (4) を添加して除蛋白を施した。 アムモニア滴下にて $\mathrm{pH}$ 7.0 としてから, 有機溶媒(クロロホルム：メチルアル コール，9:1v/v） $40 \mathrm{ml}$ を加えて 1 時間擋挥し，これ を遠心分離 $(3,000 \mathrm{rpm}, 10$ 分) 後, 有機溶媒を減圧留 去した残渣を測定試料とした。

上記の測定試料をメチルアルコールで溶解し, すみ やかに蛍光分光光度計（日立650-10S）で蛍光強度を 測定した. 励起光は398nm とし, 蛍光は Hp-D は624 $\mathrm{nm}, \mathrm{Hp}$-diAc と Hp-diSi では626nm の最大蛍光スペ クトルで測定した。この測定值を back ground (薬剤 非投与ラットの各藏器から同様の処置で得た試料の営 光強度）で補正し，別に求めた濃度営光標準曲線から 各薬剤の濃度を算出した。

\section{結 果}

1. 形態的観察所見：腫瘍組織では周辺部に限局し て赤色虽光を散在性に認めた。 Hp-D 群では投与12な らびに24時間後に強い蛍光をみたのに対し，Hp-diSi 群では蛍光はやや弱く, 投与 12 時間以降になると次第 に微弱となった。これに対して腫瘍周囲の筋組織には, 
図 1 Hp-D ならびに Hp-diSi 投与後におけるラット各組織の蛍光強度の顕微鏡観察所見 強度 $(+$ H), 中橋度 $(+)$, 弱度 $( \pm)$, 陰性 $(-)$

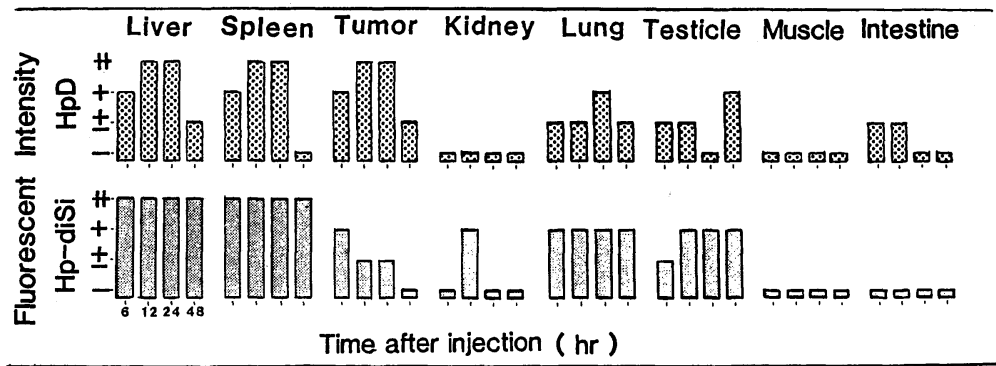

表 1 ラット組織内 Hp-D 濃度の測定結果

\begin{tabular}{cccccccc}
\hline \multirow{2}{*}{$\begin{array}{c}\text { Time after } \\
\text { injection } \\
(\mathrm{hr})\end{array}$} & Liver & Spleen & Tumor & Kidney & Lung & Testicle & Muscle \\
\cline { 2 - 8 } & $11.86 \pm 2.17$ & $2.78 \pm 0.72$ & $1.32 \pm 0.43$ & $4.27 \pm 1.51$ & $30.13 \pm 14.19$ & $0.22 \pm 0.02$ & $0.49 \pm 0.23$ \\
\hline 0 & $25.18 \pm 7.06$ & $4.17 \pm 0.96$ & $1.21 \pm 0.04$ & $1.52 \pm 0.23$ & $0.70 \pm 0.26$ & $0.25 \pm 0.03$ & $0.28 \pm 0.03$ \\
3 & $9.22 \pm 3.95$ & $2.62 \pm 0.12$ & $1.60 \pm 0.26$ & $1.68 \pm 0.37$ & $1.14 \pm 0.25$ & $0.24 \pm 0.01$ & $0.30 \pm 0.07$ \\
6 & $4.99 \pm 0.47$ & $2.24 \pm 0.19$ & $1.62 \pm 0.13$ & $1.68 \pm 0.23$ & $0.77 \pm 0.15$ & $0.24 \pm 0.07$ & $0.26 \pm 0.08$ \\
12 & $4.15 \pm 0.66$ & $1.90 \pm 0.11$ & $1.47 \pm 0.15$ & $1.50 \pm 0.07$ & $0.76 \pm 0.22$ & $0.21 \pm 0.01$ & $0.23 \pm 0.02$ \\
24 & $3.40 \pm 0.62$ & $1.83 \pm 0.01$ & $1.50 \pm 0.07$ & $1.37 \pm 0.09$ & $0.52 \pm 0.13$ & $0.21 \pm 0.04$ & $0.20 \pm 0.02$ \\
48 & $2.86 \pm 0.20$ & $1.74 \pm 0.04$ & $1.08 \pm 0.05$ & $1.23 \pm 0.09$ & $0.40 \pm 0.10$ & $0.19 \pm 0.02$ & $0.19 \pm 0.02$ \\
72 & $2.54 \pm 0.02$ & $1.68 \pm 0.03$ & $0.62 \pm 0.01$ & $0.98 \pm 0.24$ & $0.38 \pm 0.03$ & $0.18 \pm 0.02$ & $0.18 \pm 0.02$ \\
96 & & & & &
\end{tabular}

Each rat received $\mathrm{Hp}-\mathrm{D}$ i.v. $(10 \mathrm{mg} / \mathrm{Kg})$

Mean $\pm S . D$. Samples analyed (1 sample/rat)

表 2 ラット組織内 Hp-diAc 濃度の測定結果

\begin{tabular}{|c|c|c|c|c|c|c|c|}
\hline \multirow{2}{*}{$\begin{array}{l}\text { Time after } \\
\text { injection } \\
\text { (hr) }\end{array}$} & \multicolumn{7}{|c|}{$\mu \mathrm{g} \mathrm{Hp}$-diacetate/g tissue } \\
\hline & Liver & Spleen & Tumor & Kidney & Lung & Testicle & Muscle \\
\hline 0 & $37.87 \pm 26.08$ & $25.66 \pm 11.0$ & $1.66 \pm 0.54$ & $21.42 \pm 5.20$ & $30.61 \pm 4.45$ & $0.87 \pm 0.07$ & $1.65 \pm 0.42$ \\
\hline 3 & $42.09 \pm 3.97$ & $11.83 \pm 1.34$ & $1.52 \pm 0.25$ & $1.80 \pm 0.43$ & $2.73 \pm 1.22$ & $0.74 \pm 0.01$ & $0.87 \pm 0.28$ \\
\hline 6 & $29.66 \pm 4.78$ & $8.11 \pm 0.44$ & $1.20 \pm 0.45$ & $1.76 \pm 0.63$ & $2.05 \pm 0.38$ & $0.74 \pm 0.02$ & $0.79 \pm 0.06$ \\
\hline 12 & $24.71 \pm 0.53$ & $8.21 \pm 1.03$ & $0.83 \pm 0.09$ & $1.36 \pm 0.29$ & $1.35 \pm 0.41$ & $0.66 \pm 0.03$ & $0.71 \pm 0.04$ \\
\hline 24 & $23.99 \pm 4.80$ & $7.81 \pm 0.71$ & $0.82 \pm 0.05$ & $1.34 \pm 0.12$ & $0.89 \pm 0.09$ & $0.69 \pm 0.04$ & $0.69 \pm 0.02$ \\
\hline 48 & $21.20 \pm 1.80$ & $7.71 \pm 1.05$ & $0.79 \pm 0.05$ & $1.22 \pm 0.08$ & $0.86 \pm 0.10$ & $0.69 \pm 0.04$ & $0.68 \pm 0.05$ \\
\hline 72 & $14.00 \pm 1.01$ & $5.64 \pm 1.75$ & $0.69 \pm 0.03$ & $0.93 \pm 0.03$ & $0.80 \pm 0.07$ & $0.63 \pm 0.02$ & $0.67 \pm 0.02$ \\
\hline 96 & $11.51 \pm 0.74$ & $4.74 \pm 2.35$ & $0.68 \pm 0.05$ & $0.83 \pm 0.02$ & $0.73 \pm 0.04$ & $0.62 \pm 0.01$ & $0.67 \pm 0.06$ \\
\hline
\end{tabular}

Each rat received $\mathrm{Hp}$-diacetate i.v. $(10 \mathrm{mg} / \mathrm{Kg})$

Mean \pm S.D. Samples analyed ( 1 sample/rat) 
表 3 ラット組織内 Hp-diSi 濃度の測定結果

\begin{tabular}{cccccccc}
\hline \multirow{6}{*}{$\begin{array}{c}\text { Time after } \\
\text { injection } \\
\text { (he) }\end{array}$} & Liver & Spleen & Tumor & Kidney & Lung & Testicle & Muscle \\
\cline { 2 - 8 } & $5.14 \pm 0.08$ & $4.36 \pm 1.50$ & $1.67 \pm 0.62$ & $5.38 \pm 0.90$ & $8.20 \pm 3.13$ & $0.45 \pm 0.02$ & $0.38 \pm 0.06$ \\
\hline 0 & $67.02 \pm 7.65$ & $14.62 \pm 4.87$ & $1.20 \pm 0.47$ & $2.06 \pm 0.23$ & $3.76 \pm 1.19$ & $0.38 \pm 0.05$ & $0.21 \pm 0.07$ \\
3 & $83.18 \pm 18.73$ & $14.21 \pm 4.91$ & $1.18 \pm 0.48$ & $2.40 \pm 0.17$ & $3.71 \pm 1.29$ & $0.32 \pm 0.01$ & $0.29 \pm 0.01$ \\
6 & $54.74 \pm 9.00$ & $17.33 \pm 8.23$ & $1.57 \pm 0.63$ & $1.95 \pm 0.07$ & $1.38 \pm 0.14$ & $0.32 \pm 0.01$ & $0.33 \pm 0.01$ \\
12 & $68.50 \pm 4.67$ & $18.34 \pm 9.08$ & $1.97 \pm 1.27$ & $2.45 \pm 0.08$ & $1.29 \pm 0.16$ & $0.33 \pm 0.02$ & $0.30 \pm 0.01$ \\
24 & $52.87 \pm 3.80$ & $11.07 \pm 1.23$ & $1.41 \pm 0.79$ & $1.65 \pm 0.37$ & $0.97 \pm 0.20$ & $0.33 \pm 0.01$ & $0.30 \pm 0.00$ \\
48 & $61.40 \pm 8.82$ & $10.23 \pm 2.43$ & $1.01 \pm 0.32$ & $1.23 \pm 0.25$ & $0.93 \pm 0.15$ & $0.29 \pm 0.01$ & $0.27 \pm 0.01$ \\
72 & $56.85 \pm 4.48$ & $8.30 \pm 0.61$ & $0.92 \pm 0.45$ & $0.87 \pm 0.14$ & $0.72 \pm 0.06$ & $0.28 \pm 0.02$ & $0.22 \pm 0.06$ \\
96 & & & &
\end{tabular}

Each rat received $\mathrm{Hp}$-disilate i.v. (10mg/Kg)

Mean $\pm S . D$. Samples analyed ( 1 sample/rat)

両群ともに蛍光は全く観察されなかった.

肝と脾では高度の蛍光をび漫性に認め, Hp-D 群で は投与12ならびに24時間後にピークを示したが, $\mathrm{Hp}$ diSi 群では持続的に強い緹光を発した。

他藏器についてみると, 両群ともに肺と辠丸に中等 度ないし弱度の蛍光を持続的に認めたが, $\mathrm{Hp}-\mathrm{D}$ 群に 比し Hp-diSi 群でやや蛍光が強く持続する傾向をみ せた。腎と腸ではほとんぞ蛍光を認めず，腎では HpdiSi 投与12時間後に，また腸では Hp-D 投与 6 ないし 12時間後に弱い蛍光をみたのみであった。

以上の蛍光顕微鏡観察所見をむとめると，扣よそ図 1 に示すような傾向となった。

2. 定量分析結果：Hp-D, Hp-diAc ならびに HpdiSi の各臓器組織内濃度の測定值を, それぞれ表 1 , 2 ならびに 3 に示した。

Hp-D 群においては, 腫瘍で $1.21 \sim 1.62 \mu \mathrm{g} / \mathrm{g}$ の Hp$\mathrm{D}$ を投与後 48 時間にわたって検出し，72時間以降にな ると漸减した。これに対して, 腫瘍周囲筋組織内濃度 は0.18 0.49 $\mu \mathrm{g} / \mathrm{g}$ と低い值をとった。一方, 肝と脾は それぞれ $2.54 \sim 25.18 \mu \mathrm{g} / \mathrm{g}$ ならびに $1.68 \sim 4.17 \mu \mathrm{g} / \mathrm{g}$ と高い濃度範囲で経時的に漸减する傾向をみせた。腎 では投与直後に $4.27 \mu \mathrm{g} / \mathrm{g}$ とやや高值をとったが，そ れ以降は72時間まで $1.23 \sim 1.68 \mu \mathrm{g} / \mathrm{g}$ と腫瘍とほぼ同 じ水準を示した。肺は投与直後に $30.13 \mu \mathrm{g} / \mathrm{g}$ と最も高 い值をとったが，それ以降は $0.70 \sim 0.38 \mu \mathrm{g} / \mathrm{g}$ と低い 值をとった。辠丸は $0.18 \sim 0.22 \mu \mathrm{g} / \mathrm{g}$ と持続的に低い 值を示した（図 2 ).
図 2 組織内 Hp-D 濃度の経時的变化

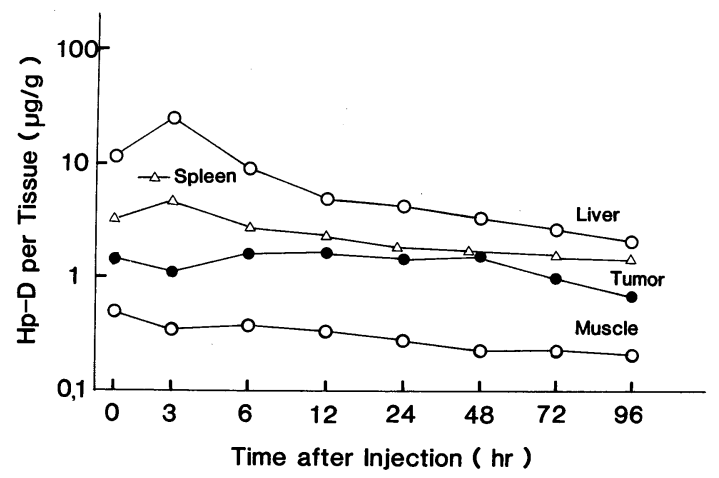

Hp-diAc 群に颃いては, 腫瘍内濃度の投与直後の $1.66 \mu \mathrm{g} / \mathrm{g}$ から 96 時間後の $0.68 \mu \mathrm{g} / \mathrm{g}$ と時間とともに 漸減した。 これに対して筋組織内濃度も投与直後の $1.65 \mu \mathrm{g} / \mathrm{g}$ から 96 時間後の $0.67 \mu \mathrm{g} / \mathrm{g}$ と, 腫瘍とほぼ同 じ水準を示した。肝, 脾, 腎, 肺ならびに辠丸の $\mathrm{Hp}$ diAc 濃度は, 前述の Hp-D の場合とほぼ同様の経時的 変化をとった（図 3 ).

Hp-diSi 群おいては, 腫瘍内濃度は48時間にわたっ て1.20 1.97 $\mu \mathrm{g} / \mathrm{g}$ の值をとり, その後やや減少して 96時間後には $0.92 \mu \mathrm{g} / \mathrm{g}$ となった。 これに対して周囲 筋組織は $0.21 \sim 0.38 \mu \mathrm{g} / \mathrm{g}$ と低い濃度を示した。一方, 腎, 肺と辠丸は Hp-D 群ならびに Hp-diAc 群とほぼ同 じ取り込み変化を示したが，肝と脾では投与 3 時間後 から持続的にそれぞれ $52.87 \sim 83.13 \mu \mathrm{g} / \mathrm{g}$ ならびに $8.30 \sim 18.34 \mu \mathrm{g} / \mathrm{g}$ と高い濃度を検出した（図 4 ）. 
図 3 組織内 Hp-diAc 濃度の経時的変化

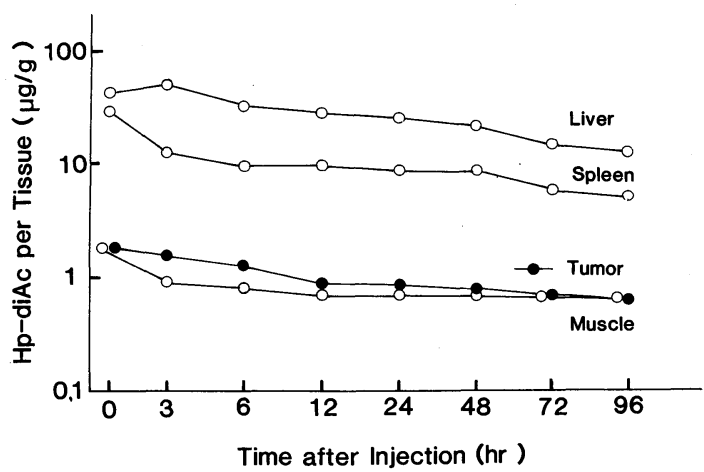

図 4 組織内 Hp-diSi 濃度の経時的変化

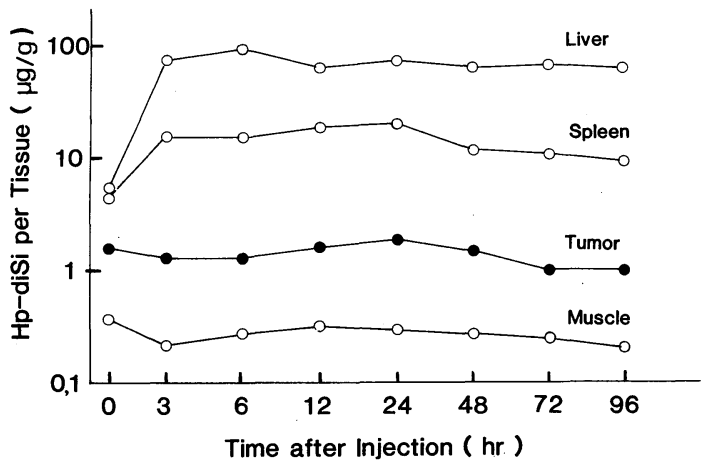

圀 5 Hp-D $(-\triangle-), H p-d i A c(\cdots \circ \cdots)$ ならびに $\mathrm{Hp}$-diSi (一・) の腫瘍/筋・取り込み比 ( $\mathrm{T} / \mathrm{M}$ 比) の経時的变化

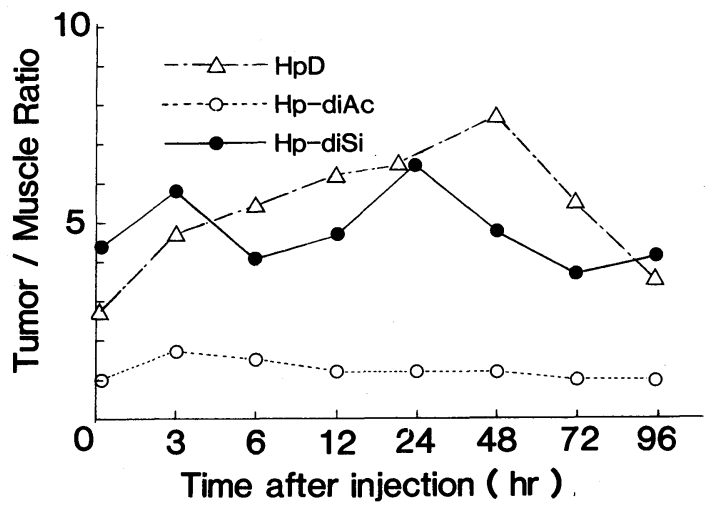

ここで各薬剂の腫瘍への取り込み率を周囲筋組織に 対する比 (tumor/muscle ratio. $\mathrm{T} / \mathrm{M}$ 比) で求めると, 以下の如くなった（図 5 ). すなわち，Hp-D の場合に は投与直後の 2.7 から48時間後の7.7へと次第に増加 し，その後急减して96時間後には 3.4 となった。 Hp-
diSi では経時的に変動があるものの，3.7から6.6と Hp-D と同様に高い値を示した。但し, 前報に打ける腹 水腫瘍への取り込みと同様に, Hp-diSi の $\mathrm{T} / \mathrm{M}$ 比の 経時変化は Hp-D に比して早期にピークをとる傾向を みせた。いずれにせよ以上の所見は Hp-D と Hp-diSi が，周囲健常組織に比して明らかに高濃度に腫瘍に取 り込をれることを示すものである。これに対して Hp$\mathrm{diAc}$ 群の $\mathrm{T} / \mathrm{M}$ 比は1.7 1.0 と常に 2 以下であり, 前 2 者に比して腫瘍親和性が少ないことが示された。

\section{考 察}

Hp-D 腫瘍親和性と営光発色現象は癌の局在診断に 応用できることから，すでに多数の臨床応用成績が報 告されている3).さらに本物質の photodynamic effect を利用した癌の治療，しなわち photoradiation therapy が開発され，Hp-D は癌の診断と治療の双方で重 要な位置を占めようとしている ${ }^{9711)}$ 。このような極め て興味ある性質をもつ Hp-D については，臨床応用を 目的として精力的な研究が行われているにもかかわら ず，今な技基本的な事項に関する検索では十分ではな い，例えば，すでに述べたごとく Hp-D の混合組成が 不安定であって腫瘍親和性の成分も確認されていない ことのほかに，この物質の生体内動態に関する情報も 少ない。

Winkelman と Rasmussen-Taxdal ${ }^{12)}$ は Wister 系 rat 大腿部皮下に移植した Walker carcinoma-sarcoma \#256を実験モデルとして, hematoporphyrin hydrochloride $20 \sim 80 \mathrm{mg}$ を腹腔内投与した所, 24 時間 後に1.4 10.2 $\mu \mathrm{g} / \mathrm{g}$ のポルフィリンを腫瘍に検出し たが，筋肉には検出し得なかったと報告した。すた Dougherty ら ${ }^{8)}$ はマクス移植乳癌に招いて，Hp-D 10 $\mathrm{mg} / \mathrm{kg}$ 腹腔内投与 24 時間後に腫瘍に $42 \mu \mathrm{g} / \mathrm{g}$ の Hp-D を検出した。しかし彼らは腫瘍と筋組織をたは肝と比 較したのみで, 他藏器に関しては検索しえない.Wharen ら ${ }^{13)}$ はラット脳腫瘍モデルに㧊いてトリチウム標 識 $\mathrm{Hp}-\mathrm{D}$ 腹腔内投与 24 時間後に $1.0 \sim 1.1 \mu \mathrm{g} / \mathrm{g}$ の腫瘍 内分布を検出している。

Hp-Dの体内動態についてアイソトープを用いて更 に詳細な研究を抗こなったのは, Gomor と Dougherty ${ }^{14)}$ 扤よび Gomer ら ${ }^{15)}$ である.

Gomor と Dougherty はマウスの移植乳癌実験系で $\left[{ }^{14} \mathrm{C}\right] \mathrm{Hp}-\mathrm{D}$ または $\left[{ }^{3} \mathrm{H}\right] \mathrm{Hp}-\mathrm{D} を 10 \mathrm{mg} / \mathrm{kg}$ 腹腔内投 与して腫瘍および臓器分布を経時的に測定した所, $\mathrm{Hp}-\mathrm{D}$ は腫瘍組織には2.39 $4.10 \mu \mathrm{g} / \mathrm{g}$, 肝には最大 $33.89 \mu \mathrm{g} / \mathrm{g}$ を検出した。また Gomer らはヌードマウ 
ス移植ヒト retinoblastoma を実験系とし $\left[{ }^{3} \mathrm{H}\right] \mathrm{Hp}-\mathrm{D}$ $20 \mathrm{mg} / \mathrm{kg}$ を腹腔内投与した所，腫瘍には $1.04 \sim 3.66$ $\mu \mathrm{g} / \mathrm{g}$ の Hp-Dを，肝に扔いては最大 $42.09 \mu \mathrm{g} / \mathrm{g}$ の Hp-Dを検出した。ここで注目すべきことは, 皮膚にも かなりの量の Hp-D が認められることで, 前者は $1.40 \sim 3.20 \mu \mathrm{g} / \mathrm{g}$, 後者では $2.69 \sim 5.27 \mu \mathrm{g} / \mathrm{g}$ の値を報 告している。このような Hp-D の皮膚分布は, Hp-D 用いた光照射療法の最大の副作用とされる，皮膚光過 敏症の原因となっている。これら諸家の報告を総括す ると, 打打よそ各臓器への Hp-D 取り込みは肝》脾,

腎》腫瘍>筋の順であり，その経時的変化と合わせて 自験成績とほぼ同じ傾向が得られている.

Hp-diAcの組織内分布については, Henderson

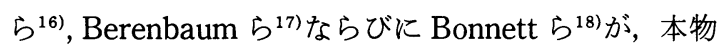
質が腫瘍組織に周囲健常部組織より多く集積すること を形態学的に観察したにとどまっていた．本物質の生 体内動態は本研究によって今回明らかにすることがで きたが，Hp-D と同様に腫瘍よりもかるかに高濃度に 肝と脾に取り込をれることが示された. Berenbaum ら ${ }^{17)}$ は Hp-D と同等以上の photodynamic effectを Hp-diAc が発揮すると報告したが, Hp-diAc の腫瘍な らびに周囲筋組織への取り込み比 ( $\mathrm{T} / \mathrm{M}$ 比) は Hp-D に比較すると明らかに低值を示した。前報で観察した 如く本物質の腹水腫崵への取り込々も比較的低值を示 した成績と考只合わせると，その腫瘍親和性は今後の 研究課題になると思われる.

Hp-diSi は本研究で開発した新しい化合物である が, Hp-D ならびに Hp-diAc と同様に肝, 脾に高濃度 に取り込まれた。しかしその $\mathrm{T} / \mathrm{M}$ 比をみると $\mathrm{Hp}$ diAc より著しく高い值をとり, Hp-D と注济同水準を 示した。この結果は腹水腫瘍への取り込みも大であっ たことと合わせて，本物質の腫瘍親和性に大きな期待 をもたせるものである。なお Hp-D と比較すると, HpdiSi の腹水腫瘍ならびに皮下固形腫瘍への取り込み はやや早期にピークに達するのが特徵である.

Kessel $^{7)}$ なびに Berenbaum ら ${ }^{17)}$ は Hp-D の既知 成分である hematoprophyrin, protoporphrin, hydroxyethyl vinyl deuteroporphrin には動物腫瘍へ の集積性が少なく, しかも光増感作用がないことを観 察し, 未知の蹯水性成分に Hp-D の有効成分が存在す ること，さらに Hp-D が細胞膜を透過するには膜透過 性に富む物質に変換する過程が必要なことを示唆し た。 その意味で蹯水性構造をもつ単一化合物である Hp-diSi は興味ある物質と言えよう。
定量分析だけでなく蛍光顕微鏡下の形態的観察にお いても, Hp-D, Hp-diAc ならびに Hp-diSi は肝と脾に 高濃度に取り込まれることが認められた。 Bugelski $ら^{19)}$ と auto radiography によって Hp-D が綱内系に 多量に分布することを観察している。すなわち肝に拈 いては肝細胞よりも Kupffer 細胞に, また脾では白脾 髄に，より多く分布することを観察している。これら ポルフィリン系物質は肝ならびに脾に発達している網 内系貪食されやすい共通性質を持つとみなされる。

一般に腫瘍組織の特徵として, 血管透過性の亢進と リンパ系の未発達が指摘されている2021). このことか ら, Bugelski ら ${ }^{199}$ は Hp-D の腫瘍集積が生じる機序を 次のように推論している。すなわち, 生体内で Hp-D は 血清タンパクとすみやかに結合し，この結合体が腫瘍 組織の血管から間質内に移行し易いこと,さらにリン パ系からの排除が少ないため腫瘍組織内に長く停滞す ることになるとみなした。著者らの観察では中心壊死 部を除く腫瘍組織に蛍光を認めたが，その分布は一様 ではなかった。 この所見は, Hp-D ないしはポルフィリ ン系物質の腫瘍集積に関与する要因として前述の腫瘍 脈管系の特異な構築が考号られるとしても, 他の因子 も関与する可能性を示唆している，例えば腫瘍間質の マクロファージがポルフィリン一蛋白結合体を選択的 に貪食することは十分に予想される所である。また， いずれの機序によって腫瘍間質に一旦集積したポル フィリンが，腫瘍細胞に選択的に取り込まれるのか否 かは今後に残された研究課題である.

\section{結 語}

AH 109A 腫瘍を皮下移植したラットを対象とし，経 静脈投与した 3 種のへマトポルフィリン誘導体の体内 動態を検索して以下の結果を得た。

1. 蛍光顕微鏡下観察で, Hp-D と Hp-diSi は腫瘍組 織の周辺部に分布し, 同時に肝ならびに脾には広範か つ高度に分布することが認められた。

2. Hp-D, Hp-diAc ならびに Hp-diSi 投与後におけ るへマトポルフィリンの組織内濃度の全般的傾向は, 肝 $>$ 脾》腫瘍, 腎, 肺 $>$ 辠丸, 腫瘍周囲筋の順であっ た。

3. 組織内濃度の推移をみると, Hp-D と Hp-diAc はいずれの組織でも時間の経過とともに漸減の傾向を みせたが, Hp-diSi では持続滞留する傾向がみられた。

4. 周囲筋組織濃度に対する腫瘍内濃度の比 $(\mathrm{T} / \mathrm{M}$ 比）みると，Hp-D と Hp-diSi ではそれぞれ7.7なら びに6.6の最高値を投与 $24 〜 48$ 時間に示し,その後減少 
した. しかし両者を比較すると, Hp-diSi ではより早期 にピークをとった。 これに対して Hp-diAcの T/M 比 は1.7〜1.0と低い水準にとどまった。

5. 以上より Hp-diSi は Hp-diAc に比して腫瘍親和 性に優れ，かつ Hp-D と異なって単一化合物であると いら特徵を有することから，今後さらに検索に值する 物質とみなされた。

\section{文献}

1) Lipson, R.L. and Baldes, E.J.: The photodynamic properities of a particular hematoporphrin derivative. Arch. Derumato, 82, 508-516, 1960.

2) Lipson, R.L., Baldes, E.J. and Olsen, A.M.: The use of a derivative of hematoprophyrin in tumor detection. J. Natl. Cancer Inst., 26, 1-8, 1961.

3) Gregorie, H.B., Horger, E.O., Ward, J.L., Green, J.F., Richards, T., Robertson, H.C. and Stevenson, T.B.: Hematoporphrin derivative fluorescence in malignant neoplasmas. Ann. Surg., 167, 820-828, 1968.

4) Kelly, J.F. and Snell, M.E. : Hematoporphyrin derivative: A possible aid in the diagnosis and therapy of carcinoma of the bladder. J. Urol., 115, 150-151, 1976.

5) Kelly, J.F., Snell, M.E. and Berenbaum, M.: Photodynamic destruction of huma bladder carcinomas. Brit. J. Cancer, 31, 237-244, 1975.

6）森 久, 加藤哲郎, 阿部良悦, 佐藤一成, 守山正 胤，鈴木敏男，佐藤栄子：Hematoporphyrin 誘道 体の腫淘親和性に関する基礎的研究 (I) Hematoporphyrin diacetate 2 Hematoporphyrin disilateの合成ならびにその特性. 日本泌 尿器科学会雑誌，投稿中.

7) Kessel, D.: Component of hematoporphyrin derivatives and their tumorlocalizing capacity. Cancer Res., 42, 1703-1706, 1982.

8) Dougherty, T.J., Grindey, G.B., Fiel, R., Weishaupt, K.R. and Boyle, D.G.: Photoradiation therapy. II cure of animal tumors with hematoporphrin and light. J. Natl. Canceer Inst., 55, 115-119, 1975.

9) Sougherty, T.J., Kaufman, J.E., Goldfarb, A., Weishaupt, K.R., Boyle, D. and Mittleman, A.: Phtoradiation therapy for the treatment of malignant tumors. Cancer Res., 38, 2628-2635, 1978.

10) Hayata, Y., Kato, H., Konaka, C., Ono, J. and Takizawa, N.: Hematoporphyrin derivative and laser photoradiation in the treatment of lkung cancer. Chest., 81, 269-277, 1982.
11) Cortese, D.A. and Kinsey, J.H.: Endoscopic management of lung cancer with hematoporphyrin derivative phototherapy. Mayo Clin. Proc., 57, 543-547, 1982.

12) Winkelman, J. and Rasmussen-Taxdal, D.S. : Quantitative determination of porphyrin uptake by tumor tissue following parenteral administration. Bull. Johns Hopkins Hosp., 107, 228-233, 1960.

13) Wharen, R.E., Anderson, R.E. and Laws, $\boxplus$.: Quantitation of hematoprophrin derivative in hjman glkomas, experimental central nervous system tumors, and normal tissues. Neurosurgery, 12, 446-450, 1983.

14) Gomer, C.J. and Dougherty, T.J.: Determination of $\left[{ }^{3} \mathrm{H}\right]$ and $\left[{ }^{14} \mathrm{C}\right]$ hematoporphyrin derivative distribution in malignant and normal tissue. Cancer Res., 39, 146-151, 1979.

15) Gomer, C.J., Rucker, N., Markm, C., Benedict, W.F. an Murphree, L. : Tissue distribution of ${ }^{3}$ $\mathrm{H}$-hematoprophyrin derivative in athymic "nude" mice heterotransplanted with human retino blastoma. Invest. Ophthalmol. Vis. Sic., 22, $118-120,1982$.

16) Henderson, R.W., Christie, G.S., Clezy, P.S. and Linehan, J.: Hematoporphrin diacetate: Aprobe to distinguish malignant from normal tissue by selective fluorescence. Br. J. Exp. Path., 61, 345-350, 1980.

17) Berenbaum, M.C., Bonnett, R. and Scourides, P. A.: In vivo biological activity of the components of hematoporphyrin derivative. Br. J. Cancer, 45, 571-581, 1982.

18) Bonnett, R., Berenbaum, M.C. and Ksu, H.: Chemical and biologucal studies on hematoporphrin derivative: An unexpective photosensitisation in brain. in Porphyrins in Tumor Phototherapy. Anderoni, A. and Cubeddu, R. ed. p. 67-79, Plenum Publishing Corp., New York and London, 1983.

19) Bugelski, P.J., Porter, C.W. and Doughrty, T.J. : Autoradiographic distribution of hematoporphyrin derivative in normal and tumor tissue of the mouse. Cancef Res., 41, 4602-4612, 1981.

20) Goldacre, R.J. and Sylven, B.: On the access of blood-borne dyes to various tumor regions. Br. J. Cancer, 16, 306-322, 1962.

21) Peterson, H.I. and Appelgren, K.L.: Experimental studies on the uptake and retention of labelled proteins in a rat tumor. Eur. J. Camcer, 9, 543-547, 1973.

（1985年11月28日受付） 